Bojan Todosijević

Center for Political Studies

and Public Opinion Research

Institute of Social Sciences

Belgrade, Serbia

bojan.todosijevic@gmail.com
UDK: 316.75:329(497.11)

Оригинални научни рад

Рад примљен: 15.09.2015.

\title{
LEFT-RIGHT IDEOLOGY: ITS MEANING AND EFFECTS ON PARTY PREFERENCES IN SERBIA ${ }^{1}$
}

Summary: Left-right ideology is regarded as an expression of socio-economic divisions. More recently, it has expanded to incorporate orientations such as nationalism or postmaterialism, and relaxed its association with social structure. Furthermore, the meaning of the political left and right varies across political contexts. As a result it is questionable to what extent left-right labels can successfully function as heuristic devices for political orientation. In order to understand the meaning of the left-right ideological dimension in a specific context it is necessary to examine the ways public responds to these labels, its socio-economic correlates, and its associations with party preferences. These tasks are undertaken in this paper, focusing on Serbia. The paper examines the readiness of Serbian respondents to identify with the leftright ideological labels, and develops a multivariate model of party preferences using socioeconomic variables and left-right scale and predictors. The study is based on data from the 2012 Serbian election study, a public opinion survey of 1568 voting age citizens of Serbia. Results indicate that about two thirds of respondents are willing to express their left-right ideological positions. This ideological dimension, however, has weak socio-economic roots, and is weakly, though significantly, associated with party preferences.

Keywords: ideology, left-right, political preference, Serbia

\section{Introduction}

Concepts of political left and right are some of the most central political notions, especially in the European context. Political journalism, common political discourse, and academic literature could hardly be conceived without these labels. They appear necessary to describe political ideologies and movements, events, political parties and actors, and

${ }^{1}$ This work was supported by the Ministry of education and science of the Republic of Serbia, project number III 47010. An earlier version of the paper was presented at the 10th Days of applied psychology, Department of Psychology of the Faculty of Philosophy, University of Niš, September 26-27, 2014, Niš, Serbia. 
other political phenomena. Political left and right are labels used for self-description as well. Individuals and groups often describe their views and preferences in terms of left and right (Fuchs \& Klingemann, 1990; Inglehart \& Klingemann, 1976). These concepts serve a number of functions - political communication, orientation, and self-description. Leftright dimension also serves as a 'cognitive short-cut', that can help the public to articulate their preferences, including selecting a party to vote for at elections, with minimal cognitive effort.

In order to perform these functions, an ideological dimension, or a set of ideological labels, needs to satisfy certain basic conditions (Todosijević, 2004). First, the public should be willing and able to use this dimension for self-description. Second, this self-labeling should be systematically related to important social and political variables. In case of the left-right dimension, this should include socio-demographic characteristics, for instance (Freire, 2008). Finally, ideological labels are useful in political orientation if they are related to political party preferences. These issues are addressed in the present paper, focusing on one particular case - Serbia. First, I examine the distribution of the left-right self placement among Serbian respondents. Next, I look into the relationships between the left-right self-placement and some of the basic socio-demographic variables. Finally, the relationships between the left-right ideology and party preferences are analyzed.

Although the intellectual traditions that gave birth to the left-right ideological discourse are located in Western Europe, the terminology gained a more global significance. Yet, the use of the left-right terminology varies both in the extent and content (e.g., Zechmeister, 2006). Apparently, the more a polity is distant from the West-European tradition, the less these concepts appear politically meaningful. The content of the dimension also varies, not only geographically but also in time. ${ }^{2}$

Given its extensiveness and variability, the meaning and function of the left-right ideological labels need to be examined and re-examined in each particular case. Without a reliable knowledge about it, any further conclusions and interpretations associated with this dimension may be inappropriate. This research is focused on contemporary Serbia, and thereby complements more theoretical and conceptual works (e.g. Bakić, 2014), and updates previous empirical findings (e.g. Mihailović, 2006; 2007).

\section{Socio-economic and demographic correlates of left-right ideology}

Despite the many apparent differences, modern societies face similar internal structural problems. Domestic political actors have to take stands towards international issues. Intellectual and cultural traditions interact and make the current globalized

\footnotetext{
${ }^{2}$ Middendorp (1991) observed that political right was initially opposed to the free-market doctrines, or that political left was more revolutionary between the two world wars than afterward. Dalton (1988) noted that the left has been taking a more post-materialist outlook since the 1960s.
} 
world ever more uniform. All these and other factors act to provide a basis for a crosscultural similarity in various attitudinal and ideological dimensions. Globalization of the contemporary world certainly does not favor insulation of particular political spaces.

At the same time, it is clear that ideological labels are to a certain extent embedded in particular social, cultural, and political contexts (Arian \& Shamir, 1983; Zechmeister, 2006). In order to derive expectations about the meaning of the left-right dimension in Serbia, here I present the most typical findings concerning the basic socio-demographic correlates of the left-right scale.

The predominant view is that the left-right dimension reflects the socio-economic division between capital and labor, in other words that it reflects a deep social cleavage (e.g. Bartolini and Mair, 1990; Kriesi, 1998; Lipset and |Rokkan, 1967; Knutsen 1995a,b; Jansen, Evans \& De Graaf, 2013). According to Huber and Inglehart (1995), in most countries the primary dimension of conflict seems to be the economic left-right cleavage. According to Knutsen, "left-right materialist value orientations are central features of political beliefs in West European societies" (1995a: 194). Left being associated with more egalitarian preferences. ${ }^{3}$

The most common practice in explaining individual and group differences in location on the dimension is the examination of its socio-demographic determinants (e.g., Freire, 2008; Himmelweit et al., 1981). For example, Middendorp (1992) examines the role of variables like age, education, income, class, and religion.

Although earlier studies reported an "astonishingly weak" association between social class and left-right positions (Inglehart and Klingemann, 1976: 265), more recent research finds that social bases of left-right dimension are important in Europe, and in some cases even increasing over time (Freire, 2008).

\section{Left-right identification and party preferences}

According to Inglehart and Klingemann (1976), political centrality of the LR dimension is supported by three components - social (location in social structure, with corresponding group identities), value (specific opinions and beliefs), and partisan (clear relationship with specific political parties). Numerous studies report significant partisan effects of LR ideology. According to Listhaug, Macdonald and Rabinovitz, for example, "in advanced industrial democracies left-right ideology is usually the single most important dimension of political competition" (1994: 111). Although some authors reported a decline of ideological polarization among political parties in Western Europe (Mair, 1998), others argue that individual LR position is still one of the most

\footnotetext{
${ }^{3}$ It has also been observed that in Western Europe left-right dimension is increasingly gaining a cultural meaning (De Vries et al., 2013).
} 
important predictors of party choice in Europe (Franklin et al., 1992; Gunter and Montero, 2001).

In Western countries, right wing identification is typically associated with the support for several groups of parties: parties promoting inegalitarian ('free market') economic policies, parties or religious background (Christian-democratic, or various denominational parties), liberal parties (those supporting extension of civil liberties, but also 'free-market'), as well as various brands of nationalist, anti-immigrant, right-wing populist parties. Left-wing identification is typical for social-democratic supporters, as well as those who support more traditional socialist ideology, as well as various forms of more extreme left party categories (communist, anarchist, and so on). So, for instance, Knutsen (2004) reports that religion is a very important determinant of party choice, both over time and across countries. Gijsberts and Nieuwbeerta found that "the left-right distinction clearly is the most relevant distinction between political parties, when investigating class-based voting" (2000: 408).

Eastern European situation shows some systematic differences. First, the dimension is a weaker correlate of party preferences, which is not surprising given the high volatility and fragmentation of these party systems. Still, parties-heirs of former communist organizations are typically on the left, while religious parties are on the right. In some Eastern European countries, left-right identification quickly followed the West-European pattern, and appeared as the strongest predictor of market liberal party preference (Kitschelt et al., 1999).

On the basis of the above outline, certain expectations about Serbia could be derived. In the global perspective, Serbia is close to the 'West' in terms of cultural and social features, and in the exposure to the main ideological currents and intellectual traditions inspiring them. Hence, the basic pattern should converge towards the Western model. However, the dominant domestic political conflict over the 1990s and 2000s has not been typically described in terms of left and right. Instead, the ideological labels prevalent in public discourse have been democratic, authoritarian, nationalist, socialist, 'regime', communist, and similar. As a result, labels left and right may be less familiar to Serbian respondents. They can be expected to abstain from expressing their own position on the scale (Mihailović, 2006). Also, when they express their position, it may be unrelated to party preferences. Both because of the uncertainty about their own positions and uncertainty about parties' positions.

Nonetheless, since the left identification is supposed to characterize those in favor of economic redistribution, it is expected that less educated and less well-off respondents should concentrate on the left-wing side of the scale. Contrary to the Western findings, where older respondents are typically more right-wing oriented, in Serbia, as in some other former socialist countries, older respondents should be more inclined to identify with the left (e.g. Mihailović, 2006). This is perhaps the most consistent reflection of so- 
cialization under the socialist system that is still noticeable even after a quarter of a century of 'transition'.

Religiosity is typically associated with right-wing identification, due to conservative nature of religious institutions, and their typical opposition to left-wing, secular and egalitarian movements. The same is expected in Serbia, as well. However, since the religious tend to be relatively older, and age in countries such as Serbia should be associated with right-wing identification, it is possible that the usual religiosity-right wing identification won't materialize in our sample. According to a survey conducted in 2002 (Todosijević, 2005), left-right scale was weakly associated with socio-economic variables. The main correlates were age and religiosity. However, left-right ideology was associated with party preferences - Socialist Party of Serbia (SPS) and to a lesser degree Serbian Radical Party (SRS) with the left identification, and DOS (Democratic Opposition of Serbia), Democratic Party of Serbia (DSS), Democratic Party (DS), and Serbian Renewal Movement (SPO) with the right.

Given the above considerations, certain expectations about the left-right ideology of the major Serbian parties, relevant in the period around the 2012 elections, can be formulated. Support for Serbian Progressive Party (SNS), given its nationalist background, should be associated with right-wing identification. Support for the SPS should be associated with the left, given its explicit socialist character. Sympathy for DSS should also be associated with right-wing identification, both due to its nationalist as well as conservative ideology. Democratic Party's (DS) supporters, however, seem to be more ambiguous. Their association with social-democracy should place them on the centerleft, but their support for market economy should move them more to the right.

\section{Method}

\section{Survey and sample}

The 2012 Serbian Public Opinion Study (SPOS) is a post-election survey of public opinion conducted after the May 2012 parliamentary and presidential elections in Serbia. The study was designed to be a nationally representative, high quality survey of public opinion, focused on explaining electoral behavior, and analyzing a broad set of attitudes, preferences, and opinions relevant to Serbian political life. The sample is selected through multiple stages of randomized selection from a national database of mailing addresses maintained by the Serbian Post.

The survey was conducted using the Computer-Assisted Personal Interviewing (CAPI) method. Data collection began on Saturday, December 21, 2012, and ran through Sunday, February 10, 2013. Incentives (a bag of coffee) were introduced to maximize both completions and response rate. The final data-set includes 1568 respondents. 
Statistical analyses presented below include weights designed to compensate for unequal sample selection probability, and to reproduce the population urban-rural proportions.

\section{Measures}

\section{Left-right self-identification}

This variable was operationalized by the following standard question:

In politics people sometimes talk of left and right. On a scale from 0 to 10 where 0 means the left and 10 means the right.

Where would you place yourself on this scale?

\section{Party sympathy}

Respondent evaluated political parties according to the degree of their dis/liking. The question text follows:

I'd like to know what you think about each of our political parties. After I read the name of a political party, please rate it on a scale from 0 to 10 , where 0 means that you strongly dislike that party and 10 means that you strongly like that party. If I come to a party you haven't heard of or you feel you do not know enough about, just say so.

\section{Demographic and socio-economic variables}

The following set of variables is used in this paper.

Gender is a standard binary variable, higher number indicating female gender.

Age is measured in years at the time of the survey.

Urbanization level has four categories

1. Rural area or village

2. Small town or medium size town

3. Suburb of a large city

4. Large city

Material possessions is a summary variable based on 5 questions asking whether a respondent or a member of his/her household owns a car, bank savings, house/apartment, and "a business, a piece of property, a farm, or livestock". The variable ranges from zero (owning nothing of the listed) up to 5 indicating possession of all of the above.

Education is operationalized in 8 categories, intended to follow the ISCED (International Standard Classification of Education) model:

1. Incomplete primary school

2. Primary school (8 years completed)

3. Incomplete secondary school

4. Completed occupational H.S. 
5. Completed 4 years H.S.

6. Higher school

7. University (BA degree)

8. Specialization, Master degree or doctorate

Religiosity is taped with the following question:

How would you describe yourself - would you say that you have (1) no religious beliefs, that you are (2) not very religious, that you are (3) somewhat religious, or that you are (4) very religious?

Religious Services Attendance is estimated with the following question:

Apart from weddings, funerals and baptisms, about how often do you attend religious services - (1) never, (2) once a year, (3) two to eleven times a year, (4) once a month, (5) two or more times a month, or (6) once a week or more?

Household income. Respondents were asked for their monthly household income, using 11 pre-defined response categories.

\section{Results}

\section{Distribution of the left-right self-placement scale}

Distribution of answers to the left-right self-placement scale, split by gender, is presented in Figure 1. The pattern of responses is similar to those often obtained in public opinion surveys of general population - there is a peak in the middle of the scale, and fewer responses towards the extremes of the scale (see Knutsen, 1998). More than one fifth of all respondents chose a middle or neutral position on the scale. It can be also observed that there are somewhat more respondents on the right side of the scale, with about ten percent of respondents identifying with the most extreme right-wing position. A particularly interesting result is the proportion of respondents that did not express a position on the scale. The current survey registered three such responses: haven't heard of left-right, doesn't know where to place oneself, and refused to answer. Nearly 30 percent of all respondents selected one of those responses, suggesting that about a third of the public is not comfortable with using this scale.

Concerning the gender differences, the responses follow a rather similar distribution. There is a slightly higher tendency for male respondents to choose one of the ideologically committed positions, i.e., both on the left and right from the central position. This is in accordance with the usual finding that males show more interest in politics and have more defined political preferences. This is corroborated with gender differences in the non-valid responses. There, about 32 percent of females chose one of the 'don't know' responses, while the same categories are selected by about 21 percent of male respondents. 
Figure 1 Distribution of left-right self-placement scores by gender

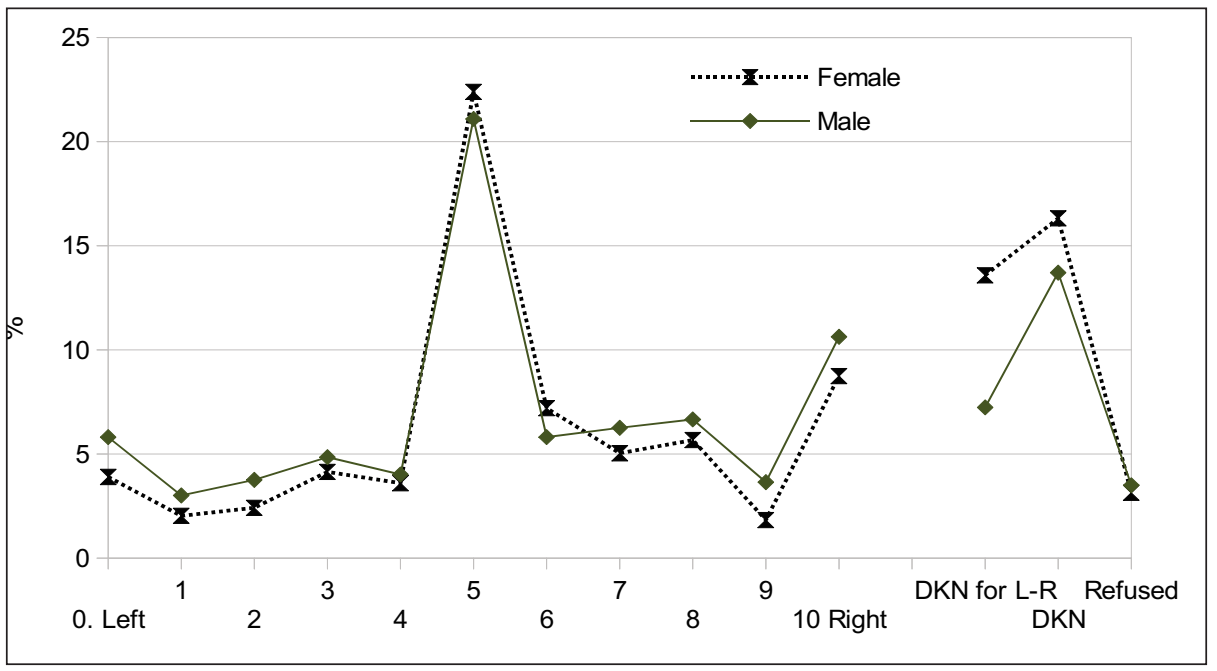

The overall impression is that most Serbian respondents are able and willing to describe their views in terms of the left-right ideological dimension. At the same time, there is a strong tendency to express the centrist or neutral position.

\section{Socio-demographic predictors of the left-right self-placement}

In this section, the ability of basic socio-demographic variables to predict leftright self-identification is examined. Table 1 shows zero-order correlation coefficients. It is clear that the association between the left-right scale and the included variables is quite weak. There are only two significant coefficients. Leftist identification is associated with older age $(r=-.08, p<.01)$, while religiosity is associated with the rightist identification $(r=.12, p<.01) .{ }^{4}$ The remaining associations are not statistically significant. Obviously, socio-economic roots of the left-right ideology in Serbia are quite weak. In addition, while the coefficient for religiosity follows the usual pattern observed cross-nationally, the association with age is more peculiar for the former communist countries. Here, older respondents are less likely to identify with rightwing.

4 These relationships are similar to those reported in Jou (2010a: 195). This is presuming that religiosity is reverse-coded by Jou; otherwise it would appear that religiosity is associated with left wing. 
Table 1 Correlation coefficients between left-right self-identification and socio-demographic variables

\begin{tabular}{|l|c|}
\hline & Correlation with L-R scale \\
\hline Gender & n.s. ${ }^{\text {a }}$ \\
\hline Age & $-.08^{* *}$ \\
\hline Urbanization & -.02 \\
\hline Material possessions & -.05 \\
\hline Education & -.01 \\
\hline Religiosity & $.12^{* *}$ \\
\hline Religious service attendance & .07 \\
\hline Income & -.06 \\
\hline
\end{tabular}

$* * \mathrm{p}<.01 .{ }^{\mathrm{a}} t$-test.

\section{Left-right ideology and party preferences in Serbia, 2012}

Ideological self-identification is weakly associated with party preferences, as shown by the correlation coefficients presented in Table 2. As expected, leftist identification is associated with a positive attitude towards SPS, but quite weakly $(r=.07, p<.05)$. A tendency of similar magnitude but opposite direction is observed for sympathies towards DSS and SNS ( $r=.08, p<.01$, and $r=.07, p<.05$, respectively). It seems that right-wing identification is more based on social conservatism and perhaps nationalist orientation rather than on liberal economic views. This is supported by the fact that the coefficients for DS, LDP (Liberal Democratic Party) and URS (United Regions of Serbia) are statistically insignificant.

Table 2 Correlation coefficients between left-right self-identification and sympathy towards political parties

\begin{tabular}{|l|c|}
\hline Party & Correlation with L-R scale \\
\hline SNS & $.07 *$ \\
\hline DS & .06 \\
\hline SPS & $-.08^{* *}$ \\
\hline DSS & $.08^{* *}$ \\
\hline LDP & .02 \\
\hline URS & .03 \\
\hline SRS & $.09 * *$ \\
\hline
\end{tabular}

${ }^{*} p<.05 ; * * p<.01$ 
In order to better evaluate the relative contribution of the left-right identification to party preferences, I performed multivariate regressions with socio-demographic variables and left-right scale together as independent variables, and party sympathy scales as dependent variables. The results are shown in Table 3 . The first impression is that the socio-demographics and left-right self-positioning taken together are able to predict party sympathy in Serbia in a statistically significant degree, but the associations are not particularly strong. The explained variance rages from three percent in case of URS up to 8 percent in case of preferences for SNS.

It can also be observed that the effect of left-right ideology onto party preferences is significant in most cases, but also rather weak. Left-wing affiliation is associated with sympathies for SPS, while sympathies for the remaining parties, apart from DSS and URS, are associated with more rightist identification. Thus, when controls for the socio-demographics are introduced, it is possible to detect more significant effects of the left-right ideology than by simply looking at zero-order correlations. Interestingly, while the zero-order correlation showed that sympathy for DSS is associated with rightist identification, the association disappeared in the multivariate model.

Among the remaining social, demographic and economic variables, several display robust and consistent effects on party preferences. The most prominent is the effect of education. Sympathy fort SNS, SPS, SRS and DSS are all negatively associated with education. Sympathy for LDP is weakly positively associated with education. Age is another major influence onto party sympathies. Older respondents are more likely to exhibit sympathies for SNS and SPS, while the younger are more positive abut DS, LDP and SRS. Gender also shows an interesting influence - female respondents appear to be more positive towards parties perceived as losers in the 2012 elections - DS and LDP.

The remaining significant effects are generally weaker and specific for only some parties. For instance, the material standard seems to differentiate sympathies for SNS and DS - support for SNS is more common among the less well-off, while the opposite tendency characterizes DS. Still, the major impression is that economic variables are poor predictors of party preferences - there are no significant associations with income and the effect of material possessions is also small.

Another interesting 'non-finding' is the lack of associations with indicators of religiosity. Among 14 possible associations, only one reached statistical significance showing that support of DSS is weakly associated with religiosity. Obviously, on the level of citizenry, religiosity matters little when it comes to party preferences.

The level of urbanization is associated with attitudes towards DSS, SRS and URS. The former two appear to be more attractive to more rural respondents, while is perceived more positively in more urban settings. 
Table 3: Multivariate regression models: $L-R$ and socio-demographic variables predicting party sympathies

\begin{tabular}{|l|l|l|l|l|l|l|l|}
\hline & SNS & DS & SPS & DSS & LDP & URS & SRS \\
\hline Gender & .02 & $.11^{* *}$ & -.01 & -.04 & $.15^{* * *}$ & .07 & .06 \\
Age & $.10^{* *}$ & $-.08^{*}$ & $.10^{* *}$ & .06 & $-.11^{* *}$ & -.04 & $-.12^{* * *}$ \\
Urbanization & -.06 & .01 & -.06 & $-.09^{*}$ & -.02 & $.09 *$ & $-.08^{*}$ \\
Material possessions & $-.09^{* *}$ & $.09^{*}$ & -.03 & -.02 & .04 & .01 & -.03 \\
Education & $-.17^{* * *}$ & .03 & $-.13^{* * *}$ & $-.08^{*}$ & $.08^{*}$ & -.06 & $-.15^{* * *}$ \\
Religiosity & .03 & -.02 & -.06 & $.10^{*}$ & -.07 & .01 & .03 \\
Religious service & & & & & & & \\
attendance & .04 & .01 & .07 & .04 & -.03 & .07 & .06 \\
Income & -.01 & .07 & .06 & .01 & .04 & -.01 & -.06 \\
Left-Right scale & $.07 *$ & $.07 *$ & $-.09^{*}$ & .04 & $.08 *$ & .05 & $.07 *$ \\
$\mathrm{R}^{2}$ & .08 & .04 & .05 & .04 & .06 & .03 & .07 \\
\hline \multicolumn{1}{|c|}{$\mathrm{F}(9,823)$} & 7.38 & 4.02 & 4.80 & 4.02 & 5.73 & 2.43 & 6.92 \\
\hline
\end{tabular}

${ }^{*} p<.05 ; * * p<.01 ; * * p<.001 ;{ }^{\mathrm{a}} p=.06$

\section{Discussion and conclusions}

According to the presented results, more than two thirds of Serbian respondents are able and willing to express their position on the left-right ideological dimension. The obtained distribution, both the proportion of invalid responses, and the tendency to provide centrist or neutral responses, is a common finding especially in the former communist countries (Freire \& Kats, 2012; Jou, 2010b; Barnes, 1998), and agrees with previous findings in Serbian research (Todosijević, 2005). Mihailović (2007: 241; see also Mihailović, 2006), for instance, reports that approximately 33\% of Serbian respondents couldn't identify with a location on the left-right scale.

This finding also confirms that traditions in political discourse are important. For instance, Granberg and Holmberg (1988), applying the left-right self-placement scale on samples from Sweden and USA found that about $94 \%$ of Swedes and only $62 \%$ of Americans managed to place themselves somewhere on the scale, and that the self-placements are relatively stable over time (though more stability is observed in Sweden). One interpretation for this pattern is that left-right terminology is less prevalent in the USA context. In Serbia, since the introduction of multi-party elections, predominant political vocabulary included labels such as nationalist, democrat, authoritarian, communist, or 'European'. Inter-party competition has been much less framed in terms of the left-right ideology. It seems that experience with democratic competitive politics is important as well. Freire (2008) reports that in newer West European democracies (e.g., Greece, Portugal) the level of recognition of the left-right terminology is lower than in older European democracies. 
Nonetheless, the basic condition for the functional use of the left-right terminology (political orientation and communication) is pretty much satisfied, as the distributional differences from the usual findings from Western Europe are not large (Knutsen, 1998). Still, a substantial portion of respondents does not relate to this dimension, suggesting that some other means of political self-definition are at work here.

The results showed that female respondents apparently feel somewhat less comfortable with the left-right scale. This can probably be explained by their lower level political interest, knowledge and political competence, and attributed to genderspecific traditional social roles and norms. Classics, studying post-WWII era politics, noted that "Wherever the consequences of women's suffrage have been studied, it would appear that women differ from men in their political behavior only in being somewhat more frequently apathetic, parochial, [and] conservative. .." (Almond and Verba, 1963: 325; see also Inglehart \& Norris, 2000).

Left-right dimension proved weakly associated with respondents' socio-demographic background, which again does not depart too much from earlier Serbian findings (e.g., Jou, 2010a; Todosijević, 2005), or Eastern European standards (e.g. Jou, 2010b). The implication is that the left-right ideology in this context is not a particularly strong expression of the socio-economic social cleavage. The obtained significant associations with age and religiosity suggest that the dimension is more associated with cultural division, and reflects the local political heritage. In this way it is possible to interpret the fact that, contrary to the usual Western findings, ${ }^{5}$ older respondents tend to lean towards the left wing (e.g., similar findings are reported in Jou, 2010a: 195; Todosijević, 2005). Obviously, socialization under the former socialist system remains influential. Religiosity, however, follows the usual pattern in being associated with the right-wing leaning. ${ }^{6}$

Since most respondents proved willing to express their left-right ideological position, the next crucial question is to what extent these positions are related to party preferences. A political-orientation device is functional if it can predict the most important political attitude in contemporary representative democracy - attitude towards political parties. The results show that, so to say, the left-right self-identification is not completely irrelevant for predicting party preferences.

According to the zero-order correlation coefficients, leftist self-placement is associated with sympathy towards the Socialist Party only. Rightist self-placement is associated with sympathies for SRS, SNS, and DSS. These findings are not surprising,

${ }^{5}$ Although studies on Western European countries also occasionally report associations between leftist identification and older age (e.g., in the Netherlands, de Vries et al., 2013).

${ }^{6}$ Jou (2010a) reports religiosity associated with left wing identification in Serbia in 1996 and 2002 (and an insignificant association in 2001). However, Todosijević (2005), using a very similar model as here, finds a modest positive association with right wing identification. 
especially if the left-right dimension is understood as taking a more cultural rather than economic meaning. The three mentioned parties are known for their social conservatism and nationalist orientation. Although SPS shares some of this ideological coloring, its socialist heritage obviously affects the perception of this party. In line with this, it has been found that in several Eastern European countries left-right self-identification is best predicted by former communist party membership (Kitschelt et al., 1999). Social liberalism or free-market economic philosophy of parties such as DS and LDP obviously hasn't found an expression in terms of the left-right ideology among the Serbian public.

The multivariate models, where left-right ideology is taken together with sociodemographics as the predictor variables, provided a more nuanced view of the association with party sympathies. Left-right ideology remains a relatively weak predictor, but here it affected preferences for additional parties. Namely, sympathies for both DS and LDP appeared associated with relatively rightist identification. According to this result, left-right scale basically differentiates the leftist SPS sympathies from the rest.

Findings from 2002 in Serbia (Todosijević, 2005: Tables 34 and 40) resemble the ones presented here, although the actual statistical models differ somewhat. ${ }^{7}$ One important difference is that, in addition to SPS, relatively leftist identification characterized also SRS sympathies, though to a smaller degree. Apparently, the role of the left-right ideological labels hasn't changed much over the last dozen years. It seems that the 2002 results corroborated Moreno's (1999) argument that since left-right terminology incorporates central political divisions, in (early) post-communist context "it should reflect the conflict between democratic and authoritarian positions in new democracies" (1999: 15). In 2012 Serbia, this was obviously not the case any more. A plausible hypothesis is that since the regime divide lost its significance, the left-right terminology hasn't yet been able to incorporate the dominant political divisions. Nonetheless, the overall impression is that the left-right identification matters for party preferences in Serbia, but it matters a little.

According to results presented in Todosijević (2008: Figures 2, 4 and 6), the association between left-right scale and party preferences was stronger in 1990 and 1996 than in 2002. The currently reported results seem to continue the trend of increasing dissociation of Serbian parties from the left-right ideology. It may be due to blurring of ideological difference between parties, and/or sharpening of other ideological differences. However, it may also be due to the decreasing relative weight of the

\footnotetext{
${ }^{7}$ Coefficients from 2002 tend to be somewhat higher than observed presently. One possible reason is that the sample from 2002 included only Belgrade residents. Hence, higher political sophistication and interest could be expected, and therefore higher ideological coherence.
} 
Socialist Party of Serbia - the only party that has remained consistently associated with leftist identification.

Concerning the included demographic and socio-economic variables, they are also not strong predictors of the left-right ideology, but some of them exhibit significant influences. Education and age demonstrated a consistent influence for a number of parties. Sympathies for parties of nationalist and socially conservative orientation (SNS, SPS, DS, SRS) are associated with lower education (similarly as in 2002, see Todosijević, 2005: Table 40). However, positive association with education is obtained only for LDP, but it is quite weak. This corroborates the interpretation that the main political divide in Serbia is more cultural (or reflecting different world-views) than economic (e.g., Todosijević, 2008; Pantić and Pavlović, 2009). The association with age generally follows the pattern obtained for education, and corroborates the cultural interpretation of the party divides. One interesting difference is that sympathy for SRS is actually associated with younger age.

Furthermore, gender gap in party preferences appeared for DS and LDP, which are more liked by female respondents. It is in line with findings that women tend to be more liberal in certain political contexts (e.g., Inglehart \& Norris, 2000). Although the main political division in Serbia seems to be cultural, it is interesting that religiosity proved to be an insignificant predictor of party preferences, except for one indicator in case of DSS. ${ }^{8}$

If we turn the attention towards specific parties, it can be observed that preferences for SNS are associated with older age, lower education and material well-being, and with rightist ideological leaning. Sympathies for SPS follow the similar pattern, except the association with leftist identification. DS and LDP sympathies also form a pair with similar predictors - female gender, younger age, and relatively leftist identification.

The overall explained variance in multivariate models, however, suggests that this set of standard socio-political variables is quite incomplete when it comes to understanding party sympathies in Serbia. Likewise, left-right ideology is a useful variable, but its influence in 2012 appears to have decreased over the previous decade (see Todosijević, 2005).

${ }^{8}$ Note that these findings are from the multivariate analysis. When zero-order relationships are analyzed, religiosity indicators appear correlated with several party preferences (similarly as in 2002 data, reported in Todosijević, 2005: Table 34). But, since the focus of this paper is on the left-right ideology, and how its links with party preferences are affected when background variables are controlled for, these results are not presented here. 


\section{REFERENCES}

Almond, G. A. \& S. Verba (1963). The Civic Culture; Political Attitudes and Democracy in Five Nations. Princeton, NJ: Princeton University Press.

Arian, A., \& Shamir, M. (1983). The primarily political functions of the left-right continuum. Comparative Politics 15(2): 139-158.

Bakić, J. (2015). Levica i desnica: pokušaj teorijskog određenja i iskustvene primene na slučaju Srbije (1990-2014). Sociologija: 57(1): 46-71.

Barnes, S. (1998). The Mobilization of Political Identity in New Democracies. In: S. Barnes \& J. Simon (eds.), The postcommunist Citizen, Budapest: Erasmus Foundation and Institute for Political Science, Hungarian Academy of Sciences (pp. 117-137).

Bartolini, S. \& Mair, P. (1990). Identity, Competition, and Electoral Availability: The Stabilisation of European Electorates, 1885-1985. Cambridge: Cambridge University Press.

Dalton, R. J. (1988). Citizen Politics in Western Democracies. Chatham, NJ: Chatham House.

De Vries, C. E., Hakhverdian, A., \& Lancee, B. (2013). The dynamics of voters' left/right identification: the role of economic and cultural attitudes. Political Science Research and Methods 1(02): 223238.

Franklin, M.N., Mackie, T.T. \& Valen, H. (eds) (1992). Electoral change: Responses to evolving social and attitudinal structures in Western countries. Cambridge: Cambridge University Press.

Freire, A. (2008). Party Polarization and Citizens' Left—Right Orientations. Party Politics 14(2): 189-209.

Freire, A. \& Kivistik, K. (2012). Left and Right in new democracies: the Baltic States and Southern Europe compared. Paper resented at the XXII World Congress of Political Science, Madrid, July 8-12, 2012

Fuchs, D., \& Klingemann, H. D. (1990). The left-right schema. In: M. K. Jennings, J. W. van Deth, S. H. Barnes, D. Fuchs, F. J. Heunks, R. Inglehart, et al. (Eds.), Continuities in political action, New York: Walter de Gruyter (pp. 203-234).

Gijsberts, M. \& Nieuwbeerta, P. (2000). Class Cleavages in Party Preferences in the New Democracies in Eastern Europe. European Societies 2(4): 397-430.

Granberg, D. \& Holmberg, S. (1988). The Political System Matters: Social Psychology and Voting Behavior in Sweden and the United States. Cambridge: Cambridge University Press.

Gunther, R., \& Montero, J. R. (2001). The anchors of partisanship: A comparative analysis of voting behavior in four South European countries. In: Diamandouros, N. \& Gunther, R. (Eds.), Parties, Politics and Democracy in the New Europe, Baltimore: Johns Hopkins (pp. 83-152).

Himmelweit, H., Humphreys, P., Jaeger, M. \& Katz, M. (1981). How Voters Decide: A Longitudinal Study of Political Attitudes and Voting Extending over Fifteen Years. London: Academic Press.

Huber, J. D. \& Inglehart, R. (1995). Expert Interpretations of Party Space and Party Locations in 42 Societies. Party Politics 1(1): 73-111.

Inglehart, R. \& Klingemann, H.-D. (1976). Party Identification, Ideological Preference and the LeftRight Dimension among Western Publics. In Budge, I., Crewe, I., \& Farlie, D. (Eds.), Party 
Bojan Todosijević, Left-Right ideology: Its meaning and effects on party preferences in Serbia

Identification and Beyond: Representations of voting and party competition, New York: Willey (pp. 243-273).

Inglehart, R., \& Norris, P. (2000). The developmental theory of the gender gap: Women's and men's voting behavior in global perspective. International Political Science Review 21(4): 441-463.

Jansen, G., Evans, G., \& De Graaf, N. D. (2013). Class voting and Left-Right party positions: A comparative study of 15 Western democracies, 1960-2005. Social science research 42(2): 376-400.

Jou, W. (2010a). Political cleavages in Serbia: changes and continuities in structuring left-right orientations. Southeast European and Black Sea Studies 10(2): 187-206.

Jou, W. (2010b). Continuities and changes in left-right orientations in new democracies: The cases of Croatia and Slovenia. Communist and Post-communist studies 43(1): 97-113.

Kitschelt, H., Mansfeldova, Z., Markowski, R. \& Tóka, G. (1999). Post-Communist Party System: Competition, Representation, and Inter-party Cooperation. Cambridge: Cambridge University Press.

Knutsen, O. (1995a). Left-Right Materialist Value Orientations. In: van Deth, J.W. \& Scarbrough, E. (Eds.), The Impact of Values, Oxford: Oxford University Press (pp. 160-196).

Knutsen, O. (1995b). Value Orientations, Political Conflicts and Left-right Identification: A Comparative Study. European Journal of Political research 28(1): 63-93.

Knutsen, O. (1998). Europeans move towards the center: a comparative longitudinal study of leftright self-placement in Western Europe. International Journal of Public Opinion Research 10(4): 292-316.

Knutsen, O. (2004). Religious Denomination and Party Choice in Western Europe: A Comparative Longitudinal Study from Eight Countries, 1970-97. International Political Science Review 25(1): 97-128.

Kriesi, H. (1998). The Transformation of Cleavage Politics. The 1997 Stein Rokkan Lecture. European Journal of Political Research 33(2): 165-185.

Lipset, S. M. \& Rokkan, S. (1967). Cleavage Structures, Party Systems and Voter Alignments. Introduction. In: Lipset, S. M. \& Rokkan, S. (Eds.), Party Systems and Voter Alignments: Cross-National Perspectives, New York: Free Press (pp. 1-64).

Listhaug, O., Macdonald, S.E. \& Rabinowitz, G. (1994). Ideology and Party Support in Comparative Perspective. European Journal of Political Research 25(2): 111-149.

Mair, P. (1997). Party system change: approaches and interpretations. Oxford: Clarendon Press.

Middendorp, C. P. (1991). Ideology in Dutch Politics: The Democratic System Revisited, 1970-1985. Assen: Van Gorcum.

Middendorp, C. P. (1992). Left-Right Self-identification and (Post)materialism in the Ideological Space; their Effect on the Vote in the Netherlands. Electoral Studies 11(3): 249-260.

Mihailović, S. (2007). Levi i desni ekstremizam u Srbiji. In: Lutovac, Z. (ed.), Ideologija i političke stranke u Srbiji, Beograd, Friedrich Ebert Stiftung/Institut društvenih nauka (str. 193-222).

Mihailović, S. (2006). Levica i desnica u Srbiji. In: Lutovac, Z. (ed.), Političke stranke i birači u državama bivše Jugoslavije, Beograd, Friedrich Ebert Stiftung/Institut društvenih nauka (str. 113-135). 
Moreno, A. (1999). Political Cleavages: Issues, Parties, and the Consolidation of Democracy. Boulder: Westview Press.

Pantić, D. \& Pavlović, Z. M. (2009). Political culture of voters in Serbia. Belgrade: Institute of Social Sciences.

Todosijević, B. (2004). The Hungarian voter: left-right dimension as a clue to policy preferences. International Political Science Review 25(4): 411-433.

Todosijević, B. (2005). Structure, Determinants and Political Consequences of Political Attitudes: Evidence from Serbia. Doctoral Dissertation. Budapest: Central European University.

Todosijević, B. (2008). The structure of political attitudes in Hungary and Serbia. East European Politics and Societies 22(4): 879-900.

Zechmeister, E. (2006). What's left and who's right? A Q-method study of individual and contextual influences on the meaning of ideological labels. Political Behavior 28(2): 151-173. 


\author{
Бојан Тодосијевић \\ Институт друштвених наука \\ Центар за политиколошка \\ истраживања и јавно мнење \\ Београд, Србија
}

\title{
ИДЕОЛОШКА ИДЕНТИФИКАЦИЈА У СРБИЈИ: ЗНАЧЕЬЕ И УТИЦАЈ НА ПАРТИЈСКЕ ПРЕФЕРЕНЦИЈЕ
}

Сажетак: Идеолошка димензија левице-деснице се обично сматра одразом соиијално-економских подела. У скорије време, значење тих термина се проширује оријентацијама као штоо су национализам или постматеријализам, док њихова укорењеност у друштвеној структури слаби. Такође је запажено да значење левице и деснице варира у зависности од друштвеног и политичког контекста. Из тога следи да је функиионалност ових одредница као хеуристичких средстава који помажу у политичкој оријентацији, упитна. Да би се разумело значење идеолошке димензије левице-деснице у одређеном контексту, потребно је испитати начине на које јавност реагује на те одреднице, како су оне повезане са друштвеном структуром и са партијским преференцијама. Наведени задаци су предузети у овом раду, фокусирајући се на Србију. У раду се анализира спремност испитаника да се идентификују са идеолошким одредницама левице и деснице, као и релације између идеолошких одредница, соиијално-економских варијабли и партијских преференција. У анализи се користе подаци постизборног истражсивања јавног мнења, спроведеног 2012. године, на случајном узорку од 1568 одраслих испитаника. Резултати указују да је око две трећине испитаника спремно да изрази свој положај да димензији левице-деснице. Веза између ове идеолошке димензије, соиијално-економских варијабли и партијских преференција је, међутим, слаба.

Кључне речи: идеологија, левица-деснища, политичке преференције, Србија 